\title{
Retinal Detachment in Preeclampsia
}

\author{
Renata Silva do Prado, Estêvão Lanna Figueiredo, Télcia Vasconcelos Barros Magalhães \\ Belo Horizonte, MG - Brazil
}

\begin{abstract}
Preeclampsia is an obstetric disease of unknown cause that affects approximately 5\% of pregnant women. The visual system may be affected with variable intensity, being the retinal detachment a rare complication. The retinal detachment in preeclampsia is usually bilateral and serous, and its pathogenesis is related to the choroidal ischemia secondary to an intense arteriolar vasospasm. The majority of patients have complete recovery of vision with clinical management, and surgery is unnecessary. This is a case report of a 27 year old patient who developed the severe form of preeclampsia on her first pregnancy. She had progressive blurred vision, until she could see only shadows. Ophthalmic examination diagnosed spread and bilateral retinal detachment. With blood pressure control at postpartum, the patient had her retina reattached, and recovery of vision.
\end{abstract}

Preeclampsia is an obstetric disease of unknown cause that affects approximately $5 \%$ of pregnant women ${ }^{1-5}$. The visual system may be affected in 30 to $100 \%$ of patients with the disease ${ }^{5}$. Retinal detachment is a rare complication of preeclampsia, affecting $1-2 \%$ of patients with its severe form and $10 \%$ of the those with eclampsia ${ }^{2,3,6,7}$. The majority of patients who manifest serous detachment during pregnancy have, with clinical management, complete recovery within weeks after delivery, and there is no need for any surgical intervention ${ }^{2,3,6,7}$. Some macular sequelae may persist, specially in the pigment epithelium ${ }^{2}$. This case shows the good clinical outcome of retinal detachment in preeclampsia, clinically managed.

\section{Case report}

A 27 years old, female, melanoderm, housekeeper, resident in Santa Luzia, MG, with no history of arterial hyper-

Serviço de Clínica Médica da Santa Casa de Belo Horizonte

Mailing address: Renata Silva do Prado - Rua Manoel Teixeira Sales, 205 - 30210 130 Belo Horizonte, MG - Brazil - E-mail: prado.renata@uol.com.br and pradorenata@hotmail.com tension and previously assymptomatic. She developed at the $28^{\text {th }}$ week of her fist pregnancy high blood pressure (140/ $90 \mathrm{mmHg}$ ) without any other symptoms, and it was tried the control with methyldopa. At the 32nd week she manifested headache, inferior limbs edema and blurred vision, and went to the hospital. Her blood pressure was $210 / 140 \mathrm{mmHg}$ and the urine analysis showed proteinuria (2,36 $\mathrm{g}$ in 24 hours). The laboratory exams didn't show trombocytopenia, liver enzymes elevation or hemolysis. She went to cesarean section, with the delivery of an alive baby and habitual bleeding. The placenta was removed in its completeness and calcified. At postpartum, the patient persisted with elevated blood pressure, lower limbs edema, proteinuria and blurred vision until she could see only shadows. Ophthalmic examination diagnosed spread and bilateral retinal detachment (figure). It was prescribed methyldopa ( $500 \mathrm{mg} \mathrm{q} 6 \mathrm{~h}$ ), nifedipine (20 mg q6h), captopril (25 mg q6h), furosemide (40 mg once daily), and she was kept at bed rest. With treatment, she had proper control of blood pressure, and the drugs dosages could be progressively reduced. The control of hypertension lead to improvement of vision. Serial ocular examination showed reattachment of the retina. After discharge from hospital, she had progressive reduction of drugs until its total withdrawn, within less then 6 weeks after delivery.

\section{Discussion}

Preeclampsia is an obstetric disease of unknown cause that affects approximately $5 \%$ of pregnant women. It can occur any time after 20 weeks of gestation and up to 6 weeks postpartum. It is characterized by the presence of elevated blood pressure, proteinuria greater then $0,3 \mathrm{~g}$ in 24 hours and edema ${ }^{1}$.

In its severe form there are observed elevated blood pressure (greater than 160/110 $\mathrm{mmHg}$, or an increase in $30 \mathrm{mmHgin}$ diastolic pressure), proteinuria greater than $2 \mathrm{~g}$ in 24 hours, central nervous system disturbances, irritability, headache, vomits, oliguria, elevated BUN, pain in the right upper quadrant and/or epigastrium, visual spots and fundoscopic 


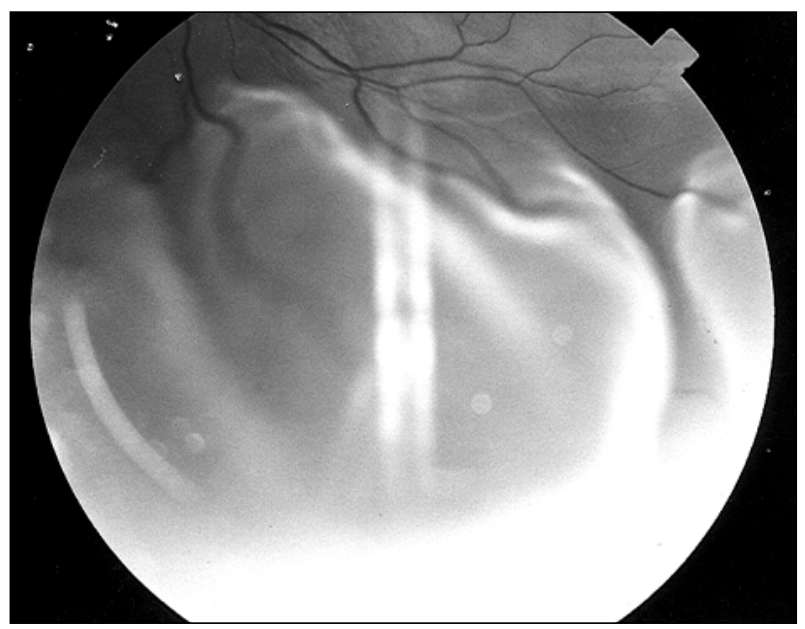

Fig. 1 - Fundoscophy of left eye showing in the inferior portion, blisters detachment of retina.

changes. HELLP syndrome may occur in the patient with the severe form and is characterized by trombocytopenia, hemolysis and elevated liver enzymes. The development of seizures in a pregnant woman with preeclampsia makes the diagnosis of eclampsia and usually leads the patient to coma. The manifestations of preeclampsia disappear within 2 20 weeks after delivery, so persistent elevated blood pressure indicates preexistent hypertension.

The visual system may be affected in 30 to $100 \%$ of patients with preeclampsia. Blurred vision is the most frequent symptom. Other signs such as photophobia, visual spots and diplopia are sometimes observed, and may be attributed to posterior cerebral artery vasospasm with ischemia, or to cerebral edema in the occipital area. Although alterations in retina and its vasculature are more common, the conjunctive, choroid, the optic nerve and visual cortex may be affected in preeclampsia ${ }^{5}$. The most prominent finding is terminal arteriolar vasospasm, associated with the development of systemic hypertension ${ }^{5}$.

Retinal detachment is a rare complication of preeclampsia, affecting $1-2 \%$ of patients with its severe form and $10 \%$ of those with eclampsia ${ }^{2,3,7}$. It may be present either before or after delivery ${ }^{9}$. It is usually bilateral, bullous and serous and the vascular alterations of preeclampsia are not so commonly seen. Some authors agree that the presence of serous retinal detachment in the mother has no prognostic implication to the fetus's life ${ }^{2}$. Others, however, believe that maternal and fetal prognosis are worse when there are fundoscopic alterations ${ }^{3,8}$.

The pathogenesis of retinal detachment is related to choroidal ischemia, secondary to an intensive arteriolar vasospasm that some patients may present ${ }^{6,7,9}$. The choroidal vascular insufficiency can lead to lesions in retinal pigment epithelium, fluid transudation and focal retinal detachment, with increasing severity ${ }^{3}$. The majority of patients who manifest serous detachment during pregnancy have, with clinical management, complete recovery within weeks after delivery, not needing any surgical intervention ${ }^{2,3,7-9}$. Some macular sequelae may persist, specially in the pigment epithelium $^{2}$. This case shows the good clinical outcome of retinal detachment in preeclampsia clinically managed.

\section{Acknowledgments}

We are in debted to the Ophtalmological Service of Santa Casa of Belo Horizonte for the collaboration received.

\section{References}

1. Corrêa MD, Corrêa JR MD. Doença hipertensiva específica da gravidez. In: Corrêa MD. Noções Práticas de Obstetrícia. Belo Horizonte: Editora Coopmed, 1999; 392-405.

2. Aburymra S. Doenças retinianas da gravidez. In: Retina e Vítreo. Clínica e Cirurgia. Sociedade Brasileira de Retina e Vítreo e Conselho Brasileiro de Oftalmologia (Ed). São Paulo: Editora Roca, 2000; 584-5.

3. Kahhale S, Zugaib M. Síndromes Hipertensivas na Gravidez (Ed). São Paulo: Atheneu, 1995; 107-21.

4. Valluri S, Adelberg D, Curtis R, et al. Diagnostic indocyanine green angiography in preeclampsia. Am J Ophthal 1996; 122: 672-7.
5. Ober RR. Pregnancy-induced hypertension (preeclampsia-eclampsia). In: Ryan SJ (ed). Retina. (2 $2^{\text {nd }}$ ed., vol. 2) St. Louis: Mosby, 1994: 1405-11.

6. Wang CL. Exudative retinal detachment in the pregnancy-induced hypertension syndrome. Chang Hua Yen Ko Tsa Chih 1992; 2: 77-9.

7. Lee C, Hsu TY, Ou CY, Chang SY, Soong YK. Retinal detachment in postpartum preeclampsia and eclampsia: report of two cases. Chang Keng I Hsueh Tsa Chih 1999; 3: 520-4.

8. Netto JA. Fundo de olho. In: Lopes M, Laurentys-Medeiros J(ed). Semiologia Médica - As Bases do Diagnóstico Clínico. Rio de Janeiro: Revinter, 2001; 249-65.

9. Bos AM, Van Loon AJ, Ameln JG. Serous retinal detachment in preeclampsia. Ned Tijdschr Geneeskd 1999; 143: 2430-2. 